\title{
VISÕES DA CONQUISTA E LEGITIMIDADE DA GUERRA: MAQUIAVEL E FRANCISCO DE VITÓRIA
}

\section{VIEWS OF CONQUEST AND LEGITIMACY OF WAR: MACHIAVELLI AND FRANCISCO DE VITORIA}

\begin{abstract}
AdRIANA BILler APARICIO
Doutoranda no Programa de Pós-Graduação em Direito da Universidade Federal de Santa Catarina (UFSC). Professora no Curso de Direito da Universidade do Vale do Itajaí. Florianópolis, SC, Brasil.

dri_biller@yahoo.com.br

Thais LuZIa Colaço

Professora Titular Aposentada da Universidade Federal de Santa Catarina (PPGD/UFSC). Direito da Universidade Federal de Santa Catarina (GPAJU/PPGD-UFSC). Professora no Curso de Direito Universidade do Extremo Sul Catarinense - UNESC thaisluziacolaco@gmail.com
\end{abstract}

\section{RESUMO}

0 artigo apresenta uma reflexão sobre a legitimidade das guerras de conquista a partir de dois clássicos do pensamento jurídico e político do século XVI: Francisco de Vitória, da Escolástica Espanhola, e Nicolau Maquiavel, italiano do Humanismo Renascentista. Valendo-se da metodologia dialética, pergunta-se sobre as diferentes visões das guerras de conquista. Para tanto, em primeiro lugar, apresenta a vida e obra dos autores estudados. Em seguida, aborda as relações internacionais na Idade Média e a formação do Estado Moderno. Posteriormente, trata de relacionar o Humanismo Renascentista e a Escolástica Espanhola. Ao final, retoma o pensamento dos autores e suas escolas para concluir que 0 pensador do século $\mathrm{XVI}$ é o homem que procura legitimar as guerras de conquista, seja com base na ordem natural ou remontando à ordem divina.

Palavras-chave: Conquista; Escolástica; Estado Moderno; Humanismo Renascentista.

\begin{abstract}
The paper presents a reflection on the legitimacy of wars of conquest from the thoughts of two sixteenth centuries' classical political and legal thinkers: Francisco de Vitoria, from Spanish Scholastic, and Niccolo Machiavelli, Italian of Renaissance Humanism. Based on the dialectic method, this work questions the different views of wars of conquest. In order to achieve its goal, at first, it presents their life and works. Then, the article studies the international relations in the Middle Ages and the formation of the Modern State. Subsequently, it relates Renaissance Humanism and Spanish Scholastic. At the end, it recapitulates the authors to conclude that the man of the sixteenth century is the man who tries to legitimize the wars of conquest, whether based on natural order or reassembling the divine order.
\end{abstract}

Keywords: Conquest; Scholastic; Modern State; Renaissance Humanism. 


\section{SUMÁRIO}

INTRODUÇÃO; 1 MAQUIAVEL E VITÓRIA: PARALELOS DE VIDA; 2 AS RELAÇÕES INTERNACIONAIS DE VASSALAGEM NA IDADE MÉDIA E A FORMAÇÃO DO ESTADO MODERNO; 3 HUMANISMO RENASCENTISTA VERSUS ESCOLÁSTICA?; 4 MAQUIAVEL E O ESPÍRITO DO HUMANISMO; 5 VITÓRIA E A LEGITIMAÇÃO DA CONQUISTA; CONCLUSÃO; REFERÊNCIAS.

\section{INTRODUÇÃO}

0 presente artigo aborda as visões sobre a legitimidade das guerras de conquista no período de transição do mundo medieval para o mundo moderno, com base em dois pensadores clássicos de diferentes escolas, Francisco de Vitória, expoente máximo da Escolástica Espanhola, e Nicolau Maquiavel, italiano do Humanismo Renascentista. Ambos os autores viveram em uma época de transição entre paradigmas de explicação do mundo, no qual se abandonava gradualmente a visão teocêntrica do medievo, representada, em regra, pelos teólogos-juristas, para se adotar a visão antropocêntrica, defendida pelos humanistas do Renascimento.

Nesta perspectiva, será problematizado em que medida a Escolástica de Francisco de Vitória e o Humanismo Renascentista de Maquiavel estiveram em oposição, e até que ponto a primeira esteve influenciada por este movimento, que, em termos de ideias filosóficas e políticas é considerada “a porta de entrada” na Idade Moderna.

Valendo-se do método dialético, no sentido de operar com "razões que se confrontam", como indicam Rubio e Varas ${ }^{1}$, apresentar-se-á em primeiro plano um breve paralelo sobre a vida destes autores, contemporâneos entre si, porém com mentalidades forjadas em mundos diferentes. Em um segundo momento, tratar-se-á da configuração do sistema de relações entre as nações no período de transição da Idade Média para a Idade Moderna, com o cenário da superação da hegemonia exercida pela Igreja Católica e do sistema de vassalagem para a formação dos particularismos de Estado. Após, será desenvolvida a correlação existente entre a Escolástica e os humanistas da Renascença, seus pontos de aproximação e afastamento, atentando-se ao fato de que a negação de Deus não era uma necessidade do homem do século XVI.

Para analisar as visões sobre a legitimidade da guerra de conquista de Maquiavel e Francisco de Vitória, tomam-se por base, respectivamente, as obras “O príncipe" e a releitura "Sobre los indios". Ao final, pretende-se, com a análise das Escolas e das respectivas obras,

${ }^{1}$ RUBIO, María José; VARAS, Jesús. El análisis de la realidad en la intervención social: métodos y técnicas de investigación. 3. ed. Madrid: CCS, 2004, p. 70. 
identificar os fundamentos teóricos do pensamento no século XVI acerca das guerras de conquista.

\section{MAQUIAVEL E VITÓRIA: PARALELOS DE VIDA}

Nicolau Maquiavel nasceu no ano de 1469 em Florença, numa Itália formada por um mosaico de pequenos estados, em um cenário de crise e dissenso, mas em meio a uma grande produção artística e cultural. ${ }^{2}$ Ao norte destacavam-se as cidades de Milão e Veneza, ao centro os Estados Papais e Florença, esta última dominada, de tempos e tempos, pela poderosa casa dos Médicis, família a cuja sorte política Maquiavel viria a ter atrelado seu destino.

A data de 1498 marcou a entrada de Maquiavel na vida pública, período no qual, como chanceler, conheceria muitas lideranças políticas, dentre elas, César Bórgia, a quem considerou a figura do novo príncipe. Em 1512, com a retomada dos Médicis ao poder, Maquiavel sofreu o exílio que o levou a intensa leitura dos clássicos, período em que surgiu "O Príncipe". ${ }^{3}$

Skinner aponta que a literatura de aconselhamento era corrente em sua época, denominada "gênero literário espelho dos príncipes" ${ }^{4}$, tendo Maquiavel dedicado a obra a Lourenço de Médicis, a quem pretendia agradar para retomar a vida pública. Maquiavel alcançou seu objetivo, não por meio deste livro, sem repercussão à época, mas por intermédio de seu amigo Vettori, embaixador de Florença em Roma, com quem travou correspondências ao longo de 1513. Seu retorno à vida pública foi breve, porque logo em seguida os Médicis novamente foram alijados do poder, e com eles o escritor florentino. Morreu no ano de $1527 .^{5}$

Sua obra "O Príncipe" foi impressa em $1532^{6}$, mas somente em 1550 propagou-se pela Europa. As repercussões de seu livro são intensas, tendo sido o autor difamado e a ele atribuídas diversas arbitrariedades e assassinatos por parte de tiranos. Seu livro foi colocado no Index da Igreja em 1557. Influenciado pela visão cíclica dos acontecimentos e pela fé na criatividade

\footnotetext{
${ }^{2}$ CHEVALLIER, Jean-Jacques. A grandes obras políticas de Maquiavel a nossos dias. 8. ed. Rio de Janeiro: Agir, 2002, p. 17-25.

${ }^{3}$ SADEK, Maria Tereza. Nicolau Maquiavel: o cidadão sem fortuna, o intelectual de virtú. In: WEFFORT, Francisco C. (Org.). Os clássicos da política. (Vol. 1). 2. ed. São Paulo: Ática, 1991, p. 14-17.

${ }^{4}$ SKINNER, Quentin. As fundações do pensamento político moderno. São Paulo: Companhia das Letras, 1996, p. 139.

${ }^{5}$ MARTINS, Carlos Estevam (Consult.). Maquiavel: vida e obra. In: MAQUIAVEL, Nicolau. O Príncipe e escritos políticos. 4. ed. São Paulo: Nova Cultural, 1987. (Os Pensadores), p. VII-XXI.

${ }^{6}$ BARTH, Sérgio. Maquiavelismo: a prática política segundo Nicolau Maquiavel. São Paulo: Ática, 1992. (Série Princípios). p. 27.
} 
humana para determinar o rumo dos acontecimentos, típico pensamento renascentista, o autor é reconhecido hoje como um marco do pensamento político moderno.

Apenas um ano antes da morte de Maquiavel ocorrida em 1527, Francisco de Vitória (1483-1546) ingressou na cátedra da Universidade de Salamanca, onde se tornou célebre por suas Releituras, sendo tradicionalmente apontado como um dos fundadores do Direito Internacional Moderno. Nascido em Burgos (Espanha), sua formação intelectual teve por base a escolástica tomista. Iniciou os estudos no Convento São Paulo, da ordem dominicana, complementando-os no convento de Santiago de Paris e, na Universidade desta mesma cidade, obteve o título de Doutor em Teologia em 1522.

O destaque de sua obra deu-se por meio das suas Releituras ou Repetições que consistiam em tratados sobre temas monográficos expostos de forma solene a toda comunidade universitária. É importante observar que seus manuscritos não chegaram à época contemporânea, mas tão somente as anotações de seus alunos. ${ }^{7}$

Se durante a Idade Média a razão teológica foi fonte e justificação da razão política e jurídica, já no século XVI, considerado por Enrique Dussel ${ }^{8}$ como "a primeira modernidade" buscando incluir no conceito a incorporação da América Indígena como estrutura fundamental no novo "sistema-mundo" de dominação -, o direito buscou independência da teologia, e esta realidade não escapou das análises dos teólogos, filósofos e juristas.

Neste sentido, verifica-se que Maquiavel foi um homem formado fora dos domínios intelectuais da Igreja. Em seus escritos, o autor rompeu com a preocupação finalista de uma ordem natural e com desígnios divinos. Francisco de Vitória, apesar de ser uma mentalidade forjada no seio do cristianismo, representa o germe do pensamento moderno, sem se afastar da ordem natural tomista, sofrendo influências do humanismo. Ambos os pensadores, apesar de originários de diferentes escolas de pensamento político, trataram de justificar as guerras de conquista, que envolvem um exército organizado, um povo que se quer dominar e a posterior administração de seus bens. ${ }^{9}$

\footnotetext{
${ }^{7}$ RUIZ, Rafael. Francisco de Vitoria e os direitos dos índios americanos. Porto Alegre: EDIPURS, 2002, p. 61.

${ }^{8}$ DUSSEL, Enrique. Ética da libertação: na idade da globalização e da exclusão. Petrópolis: Vozes, 2000, p. 51.

9 SOUZA LIMA, Antonio Carlos de. Um grande cerco de paz: poder tutelar, indianidade e formação do Estado no Brasil. Petrópolis: Vozes, 1995, p. 49.
} 


\section{AS RELAÇÕES INTERNACIONAIS DE VASSALAGEM NA IDADE MÉDIA E A FORMAÇÃO DO ESTADO MODERNO}

No que diz respeito às concepções de conquista, o paralelo entre o pensamento de Nicolau Maquiavel e Francisco de Vitória sugere uma abordagem das relações de poder estabelecidas ao longo da Idade Média.

A coroação de Carlos Magno pelo Papa Leão III em Roma, no ano de 800, marcou a continuidade simbólica do Império Romano ${ }^{10}$, estabelecendo uma dualidade de poder do Papado e do Império, que entraram em constante correlação de forças durante a Idade Média. Apesar do malogro do estabelecimento do império de Carlos Magno, depois retomado em 962 pela coroação do rei da Oto I da Germânia, consolidou-se a Respublica Christiana que simbolizava a unidade da cristandade ocidental. Antonio Truyol e Serra explica o conceito: “Em uma palavra, a Respublica Christiana de que falam as fontes da época era um corpo social hierarquizado, mas não unitário, uma communitas communitatum sob a direção mais ou menos efetiva do Papa e do Imperador" 11 (tradução nossa).

A concepção de um império universal estava de acordo com o sistema feudal, alheio ao moderno conceito de soberania, pelo qual o Estado, com suas fronteiras delimitadas e ordem própria, não conceberia um poder superior ao seu. Isto porque o sistema de vassalagem internacional, estando na cúpula a Igreja e o Império, justificava-se na necessidade de proteção, e a dependência não era, segundo Weckmann, motivo de humilhação alguma:

[...] esta concepção de mundo como unidade e aceitação - ao menos em teoria de uma só autoridade imperial para todo o orbe, é factível no seio de uma sociedade que, como a europeia da Baixa Idade Média, desconhecia ou dava pouca importância ao espírito nacionalista. ${ }^{12}$ (tradução nossa).

\footnotetext{
${ }^{10}$ WECKMANN, Luis. El pensamiento político medieval y los orígenes del derecho internacional. 2. ed. Mexico DF: Fondo de Cultura Mexicano, 1993, p. 29.

${ }^{11}$ No original: "En una palabra, la Respublica Christiana de la que hablan las fuentes de la época, era un cuerpo social jerarquizado, pero no unitario, una communitas communitatum bajo la dirección más o menos efectiva del Papa y del Emperador". In: TRUYOL Y SERRA, Antonio. Historia del Derecho Internacional Público. Madrid: Tecnos, 1998, p. 32.

${ }^{12}$ No original: “[...] esta concepción del mundo como unidad y aceptación -al menos en teoría - de una sola autoridad imperial para todo el orbe, es factible en el seno de una sociedad que, como la europea de la baja Edad Media, desconocía o daba poca importancia al espíritu nacionalista". In: WECKMANN, Luis. El pensamiento político medieval y los orígenes del derecho internacional. 2. ed. Mexico DF: Fondo de Cultura Mexicano, 1993, p. 29.
} 
0 mundo medieval do Ocidente era concebido como uma unidade em torno da cristandade, marcado pela descentralização e hierarquia do poder político, estando ausentes conceitos de fronteira, territórios, estado ou soberania nacional. Segundo Crossman, “[...] durante séculos a Igreja Católica deu à Europa Ocidental uma cultura comum que todos os reis e senhores aceitaram" ${ }^{13}$.

No entanto, esta visão teocêntrica e hierárquica sofreu alterações por razões de cunho social e econômico. No campo das ideias, destacou-se a recuperação das obras de Aristóteles no século XI e XII. A sua principal influência, no que diz respeito à teoria do Estado, foi a recuperação de seu sentido clássico, o Estado como uma comunidade completa em si mesmo e, ainda, de localizar a soberania a partir da sociedade. ${ }^{14}$

No século XIII começaram a surgir na França os primeiros particularismos de Estado. Publicistas franceses passaram a questionar a universalidade do poder do Império, numa tendência de tornar autônomo o poder do Estado, destacando-se autores como Juan de París e Pierre Dubois. A Igreja perdeu muito de sua força e Felipe, o Belo, passou, ainda neste século, a não reconhecer outro poder superior ao seu.

A tendência de secularização do Estado definiu-se com maior clareza na primeira metade do século XIV. ${ }^{15}$ Neste momento de controvérsias entre Igreja e Papado, destaca-se o pensamento de Guilherme de Occam e Marsílio de Padua. Na obra “Defensor Pacis”, Marsílio de Padua revolucionou o pensamento político medieval ao atacar a primazia de uma lei natural sobre as instituições terrenas. Para Marsílio, a justificação da lei está no próprio Estado, redigida pelo legislador:

[..] a lei, que dentro do esquema tomista é anterior ao poder político, e condição e limite do mesmo, aparece agora em Marsilio identificada com o Estado, cuja criação é a lei e o toque de distinção do estado marsiliano, e encontra sua origem na vontade popular. ${ }^{16}$ (tradução nossa)

\footnotetext{
${ }^{13}$ No original: “[...] durante siglos la Iglesia católica dio a la Europa occidental una cultura común que aceptaron todos los reyes y señores". In: CROSSMAN, Richard Howard Stafford. Biografía del Estado Moderno. 2. ed. Madrid: Fundo de Cultura Económica de España, 1965, p. 25.

${ }^{14}$ WECKMANN, Luis. El pensamiento político medieval y los orígenes del derecho internacional. 2. ed. Mexico DF: Fondo de Cultura Mexicano, 1993, p. 161.

${ }^{15}$ WECKMANN, Luis. El pensamiento político medieval y los orígenes del derecho internacional. 2. ed. Mexico DF: Fondo de Cultura Mexicano, 1993, p. 169.

${ }^{16}$ No original: “[...] la ley, que dentro del esquema tomista es anterior al poder político, y condición y límite del mismo, aparece ahora en Marsilio identificada com el Estado, cuya creación es; la ley es el toque de distincíon del estado marsiliano, y encuentra su origen en la voluntad popular." In: WECKMANN, Luis. El pensamiento político medieval y los orígenes del derecho internacional. 2. ed. Mexico DF: Fondo de Cultura Mexicano, 1993, p. 172.
} 
A reforma protestante desferiu o golpe fatal neste sistema de poderes universais. 0 movimento protestante encontrou seu aliado maior na figura do príncipe e a Europa protestante tomou por princípio que os súditos deveriam seguir a religião do rei, passando a religião a ser negócio do Estado. O poder desenvolveu seu marco geográfico, surgindo a ideia de soberania ligada ao território. Assim, começou-se a forjar um conceito de nação ligado ao território. Os povos, que antes se viam unidos pela religião, passaram a ver suas particularidades, a religião foi perdendo sua supremacia e o Direito fundaria o Estado Moderno. É sob este novo paradigma que Maquiavel pensou sua obra "O Príncipe", operando a separação entre a Política e a Teologia.

Francisco de Vitória, apesar de ser teólogo, não deixou também de tratar desta realidade social e política a partir de uma nova ótica, que nega o poder temporal do Papa sobre o orbe e, portanto, ordem hierárquica medieval. Ao tratar da origem jusnaturalista da soberania externa, Ferrajoli ${ }^{17}$ considera que o pensamento de Vitória goza de excepcional modernidade, por atribuir a configuração da ordem mundial como sociedade natural de Estados soberanos, com base em direitos naturais dos povos. Para ele, a origem da reflexão sobre soberania externa em Vitória está ligada à exigência eminentemente prática de oferecer um fundamento jurídico à Conquista do Novo Mundo.

\section{HUMANISMO RENASCENTISTA VERSUS ESCOLÁSTICA?}

O termo Renascimento foi criado pelos humanistas que, com base na ideia cíclica dos acontecimentos históricos, imaginavam-se representantes do fim do período das trevas. Consideravam-se agentes das mudanças, protagonistas do retorno à vida, da retomada da cultura clássica.

Ao demonstrar que a Renascença italiana encontrou nos estudos das artes retóricas e do currículo escolástico suas raízes, Quentin Skinner ${ }^{18}$ dá conta da relação de continuidade existente entre um e outro e aponta que o movimento intelectual do Humanismo cristalizou sua própria identidade em oposição à Escolástica. Os humanistas opunham-se aos escolásticos com relação ao método, especialmente na interpretação do direito romano, entendendo os primeiros que este deveria ser objeto de um estudo histórico e não “atualizante” para aplicação no seu

\footnotetext{
${ }^{17}$ FERRAJOLI, Luigi. A soberania no mundo moderno: nascimento e crise do Estado Nacional. São Paulo: Martins Fontes, 2002, p. 6.

${ }^{18}$ SKINNER, Quentin. As fundações do pensamento político moderno. São Paulo: Companhia das Letras, 1996, p. 125.
} 
tempo. Além disso, também eram contra a postura meramente teórica dos escolásticos e sua incapacidade de lidar com problemas sociais e políticos de sua época. Esta postura, segundo Skinner ${ }^{19}$, leva-se a entender o legado das ciências da experiência pelos humanistas.

Além de se voltar para uma atuação mais secular, os humanistas questionavam teses centrais do cristianismo agostiniano. A adoção, pelos humanistas, da visão cíclica dos acontecimentos humanos entrava em contrariedade com a linearidade adotada pela Igreja.

Se a contenda entre humanistas e escolásticos é algo visível nas críticas traçadas pelos primeiros aos segundos, não é verdade que o humanismo tenha sido anticlerical. Isso nos aponta Braudel: "o humanismo do Renascimento é o diálogo de Roma com Roma, da Roma pagã com a Roma de Cristo, da civilização antiga com a civilização cristã”. ${ }^{20}$ É assim que alerta o historiador: “o pensamento europeu não se concebe senão no âmbito do diálogo com o cristianismo, mesmo quando o diálogo é candente ou violenta a discussão". ${ }^{21}$

O Humanismo Renascentista é datado cronologicamente, segundo Braudel ${ }^{22}$ - entre 1337 e 1530 -, mas sua influência se expande para o passado e futuro e para além da Itália. Para o passado, porque o humanismo não foi uma ruptura total com a filosofia medieval, e para o futuro, porque até os dias de hoje a Europa ainda guarda a marca da confiança na grandeza e inteligência humana. Entre o Humanismo e o Cristianismo, percebe-se uma diferença maior no ensino tradicional da escolástica do que o fundo filosófico, pois, segundo Braudel ${ }^{23}$, a negação de Deus não era preocupação ou necessidade do homem do século XVI.

No campo da legitimação da guerra de conquista, a literatura teológica diferencia-se da posição humanista. Apesar de ambas trabalharem a partir do conceito de guerra justa, lembra Diego Panizza, em introdução à obra de Gentilli, que o debate dava-se no âmbito das justificações do uso da força:

Em geral a tradição humanista tendia a justificar um amplo conjunto de "causas justas", enquanto a teológica se atinha a uma concepção austera e restritiva da violência, de tipo rigorosamente jurisdicional, admitindo-a somente como mera restauração do direito violado. ${ }^{24}$

\footnotetext{
${ }^{19}$ SKINNER, Quentin. As fundações do pensamento político moderno. São Paulo: Companhia das Letras, 1996, p. 128.

${ }^{20}$ BRAUDEL, Fernand. Gramática das civilizações. São Paulo: Martins Fontes, 2004, p. 316.

${ }^{21}$ Ibidem, p. 313.

${ }^{22}$ Ibidem, p. 317.

${ }^{23}$ Ibidem, p. 319.

${ }^{24}$ PANIZZA, Diego. Introdução. In: GENTILI, Alberico. 0 direito de guerra. Ijuí: Unijuí, 2005, p. 35.
} 
No século $\mathrm{XVI}$, houve uma renovação no direito de guerra em razão da formação dos Estados Modernos. Ferrajoli aponta o que considera uma ideia basilar de Francisco de Vitória:

[..] uma nova doutrina de legitimação da guerra justa [..] redefinida como reparação das injúrias e portanto, como instrumento de atuação do direito. Disso resulta uma configuração jurídica da guerra como sanção voltada a assegurar a efetividade do direito internacional, que permanecerá inalterada até o século XX e chegará até Kelsen. ${ }^{25}$

Neste sentido, ao passo que Vitória ainda trabalhava com o direito de predicação do evangelho aos povos ameríndios, ao qual eles não podiam se opor sem justa causa, para o humanista Alberico Gentili, admirador de Nicolau Maquiavel, não se justificavam, de forma alguma, as guerras por motivos religiosos. Diego Panizza aponta, na introdução da obra citada de Gentili, que "não eram justificadas as guerras entre cristãos, assim como não o eram as guerras feitas pelos 'conquistadores' para a conversão dos índios na América". ${ }^{26}$ A tradição humanista, apesar de não aceitar a guerra por religião, justificava a expansão colonial na América em nome da civilização cristã.

Apesar das diferenças apontadas entre Escolástica e Humanismo, identifica-se a formação de uma nítida separação entre a moral teológica e as diretivas do Direito: “É processo de autonomia que acaba por tornar independente Estado e Moral, como quis Maquiavel". ${ }^{27}$

Os teólogos da escolástica espanhola, da qual Francisco de Vitória é um dos maiores expoentes, são considerados filósofos da primeira modernidade: não renunciam à tradição medieval tomista, mas também sofrem fortes influências do humanismo. Ao reconhecerem a autonomia do ser humano fundada na sua liberdade, lançam bases teóricas para o direito moderno. ${ }^{28}$

Os humanistas da Renascença trabalhavam com o "caldo cultural” que desaguaria na ideia de Estado-nação, em fronteiras que seriam delimitadas na Europa, com o Tratado de Vestfália, no ano de 1648. A consagração das liberdades de religião do Estado implicaria na consolidação do marco de soberania a partir da visão do homem europeu, com a superação do debate da legitimidade da Conquista da América.

\footnotetext{
${ }^{25}$ FERRAJOLI, Luigi. A soberania no mundo moderno: nascimento e crise do Estado Nacional. São Paulo: Martins Fontes, 2002, p. 12-13.

${ }^{26}$ PANIZZA, Diego. Introdução. In: GENTILI, Alberico. 0 direito de guerra. Ijuí: Unijuí, 2005, p. 32.

${ }^{27}$ WECKMANN, Luis. El pensamiento político medieval y los orígenes del derecho internacional. 2 . ed. Mexico DF: Fondo de Cultura Mexicano, 1993, p. 172.

${ }^{28}$ RANGEL, Jesús Antonio de la Torre. El derecho como manifestación del humanismo clásico español: Francisco de Vitória, Luis de Molina y Francisco Suárez. In: WOLKMER, Antônio C. Fundamentos do humanismo jurídico no Ocidente. Barueri: Manole; Florianópolis: Funjab, 2005, p. 82.
} 


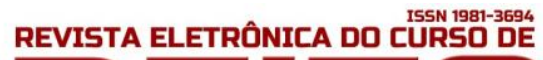

\section{MAQUIAVEL E O ESPÍRITO DO HUMANISMO}

O principal traço característico dos humanistas é a crença no conceito ciceroniano de virtú humana, enfatizando no homem, suas virtudes, para alcançar o máximo grau de sua excelência. Isto os levou a negar por completo a concepção agostiana da natureza humana. Skinner alerta, no entanto, que isto não representa, de forma alguma, um retorno ao paganismo. ${ }^{29}$ No pensamento humanista, portanto, o homem de virtú, ao contrário do homem agostiniano, seria capaz de superar qualquer obstáculo que the aparecesse no caminho. 0 retorno à imagem clássica das virtudes humanas produz, nos humanistas, uma concepção de homem como senhor de seu destino.

Maquiavel insere-se no que Skinner ${ }^{30}$ denomina humanismo da Renascença tardia, que coincide com governos de príncipes. Em contraposição ao humanismo dos Quatrocentos - o humanismo cívico com base na república e nas liberdades cívicas -, o humanismo tardio centraria sua atenção na figura do príncipe.

Neste momento é que encontrariam destaques os livros de aconselhamento, sendo "O Príncipe" (1513) de Maquiavel a obra mais célebre. Estes autores, porém, continuavam a enfatizar o papel da virtú nos negócios humanos, tratando das qualidades que deveria ter um governante.

Se para os humanistas cívicos o bom governo deveria objetivar a liberdade e a justiça, os humanistas do século XVI preocupavam-se com a conservação da paz. Outra importante inovação é que os teóricos dos príncipes passaram a estabelecer diferenças entre virtude privada e virtude pública. Maquiavel apresentou a virtú do príncipe como uma força espantosamente criativa, "[..] a chave para que ele mantenha seu estado e se capacite a esmagar seus inimigos". 31

Em Maquiavel há uma ruptura radical: o florentino quis resolver a questão da instabilidade política rompendo com a ideia de ordem natural. A ordem, produto da política, deveria ser construída pelo homem e não seria definitiva, haveria sempre um movimento negativo.

\footnotetext{
${ }^{29}$ SKINNER, Quentin. As fundações do pensamento político moderno. São Paulo: Companhia das Letras, 1996, p. 114.

${ }^{30}$ Ibidem, p. 143.

${ }^{31}$ MAQUIAVEL, Nicolau. O príncipe. 2. ed. São Paulo: Martins Fontes, 1999, p. 146.
} 
Ao contrário do que traçaram os seus contemporâneos teólogos-juristas, o autor não discutiu a legitimidade da guerra, pois para Maquiavel o desejo de conquista era algo natural. Afirmou o autor no capítulo III: “É, de fato, muito natural e comum o desejo de conquistar. Quando, podendo, os homens o realizam, merecem ser louvados e não criticados [...]". ${ }^{32}$ No pensamento de Maquiavel, a razão de Estado prevaleceria como único limite na conduta do soberano.

O autor de "O Príncipe" não se preocupou em atacar o poder espiritual ou temporal da Igreja, cuidando tão somente de analisá-la como um poder secular dentre seus domínios. É assim que observou, no capítulo dedicado aos Estados Eclesiásticos: “[...] Mas, sendo eles regidos por razões superiores, que a mente humana pode alcançar, não falarei sobre eles, pois sendo erguidos e mantidos por Deus, seria um homem presunçoso e temerário se discorresse a seu respeito". 33

A virtude de se manter no poder mediante a arte da dissimulação, abordada no capítulo XVIII, foi elogiada nas ações do Papa Alexandre VI. Maquiavel explicou como o pontífice conseguiu, com armas e dinheiro, aumentar o poder da Igreja na Itália, e tendo Leão herdado uma posição mais favorável, pondera que: “Portanto, Sua Santidade o papa Leão encontrou este pontificado potentíssimo e, se outros o engrandeceram com as armas, dele se espera que o torne imenso e venerando com sua bondade e suas outras infinitas virtù". ${ }^{34}$

Se o autor rompeu com o ethos cristão, porque seu principal objetivo era a manutenção do poder, o fortalecimento da Igreja também poderia representar um óbice ao bom governo. Desta forma, considerou um erro de Luís XII ter ajudado o Papa Alexandre a ocupar outros territórios, como afirmou em capítulo III da obra analisada: “[...] arruína-se quem é instrumento para que outro se torne poderoso, porque esse poder é dado pela astúcia ou pela força e ambas são suspeitas a quem se torna poderoso". 35

Apesar de ter analisado o poder político de forma desvinculada da moral cristã, Maquiavel também soube elogiar a conduta do príncipe que expande seus domínios, sob pretexto da religião. Assim se referiu a Fernando de Aragão, no capítulo XXI, para ele o primeiro soberano da Cristandade, em fama e glória: “[...] além disso, para poder realizar maiores feitos, servindo-

\footnotetext{
${ }^{32}$ MAQUIAVEL, Nicolau. O príncipe. 2. ed. São Paulo: Martins Fontes, 1999, p. 14.

33 Ibidem, p. 53.

34 Ibidem, 1999, p. 55.

35 Ibidem, 1999, p. 16.
} 
se sempre da religião, voltou-se para uma piedosa crueldade, expulsando e saqueando os marranos de seu reino $[\ldots] "{ }^{36}$

Para Lauro Escorel de Moraes ${ }^{37}$, Maquiavel reduziu a política a uma técnica que derivou no despotismo totalitário, pois conferiu valor supremo à autoridade do Estado, no qual as ações são julgadas tão somente em razão de sua utilidade. Sua postura, segundo o autor, seria retomada no século XVII por Bacon, Bodin, Spinoza e Hobbes, inserindo Maquiavel na raiz da concepção política que não reconhece limite ao poder do Estado. Neste contexto também é que Chevalier $^{38}$ insere o pensamento de Maquiavel ao lado dos teóricos do absolutismo.

A separação da política e teologia fez com que no plano internacional se justificasse o que posteriormente denominou-se por estado de natureza hobbesiano, ou soberania externa absoluta, que tem a guerra por princípio. 0 mundo dividido em estados, sem que sobre estes reconheçam autoridades superiores, é a expressão máxima da soberania moderna, que culminaria, segundo a historiografia, com a divisão europeia sancionada na Paz de Vestfália, em 1648.

É assim que Luigi Ferrajoli aponta a crise dos ideais do teólogo da Escola de Salamanca, Francisco de Vitória, sobre o ideal de uma comunidade universal das gentes, com limites impostos pelo direito natural:

[..] é no século XVII que o modelo vitoriano entra definitivamente em crise. Com a consolidação dos Estados nacionais e com sua plena autonomização dos vínculos ideológicos e religiosos, que haviam cimentado a civitas christiana (nação cristã) sob a égide da Igreja e do Império, cai todo e qualquer limite à soberania estatal e se completa, com sua plena secularização, sua total absolutização. ${ }^{39}$

Maquiavel entendia que a manutenção do poder deveria ser feita não somente pela lei, mas também pelas armas. No capítulo XII considerou que: “[...] os principais fundamentos de todos os estados, tanto dos novos como dos velhos ou dos mistos, são boas leis e boas armas". ${ }^{40}$ Defendeu no capítulo VI que na consolidação do poder o príncipe deveria se valer das armas,

\footnotetext{
${ }^{36}$ MAQUIAVEL, Nicolau. O príncipe. 2. ed. São Paulo: Martins Fontes, 1999, p. 105.

${ }^{37}$ MORAES, Lauro Escorel. Maquiavel e o pensamento político. Maquiavel: um seminário da Universidade de Brasília, Cadernos da UnB. Brasília. Editora Universidade de Brasília. 1981. p. 15-28.

${ }^{38}$ CHEVALLIER, Jean-Jacques. A grandes obras políticas de Maquiavel a nossos dias. 8. ed. Rio de Janeiro: Agir, 2002. p. 17-99.

${ }^{39}$ FERRAJOLI, Luigi. A soberania no mundo moderno: nascimento e crise do Estado Nacional. São Paulo: Martins Fontes, 2002, p. 16-17.

${ }^{40}$ MAQUIAVEL, Nicolau. O príncipe. 2. ed. São Paulo: Martins Fontes, 1999, p. 57.
} 
quando cessada a imposição da lei ou do consenso: "Por isso, convém estar organizado de modo que, quando não acreditarem mais, seja possível fazê-los crer à força”. ${ }^{41}$

Em "O Príncipe", Maquiavel traçou os contornos do Estado moderno, livre de legitimidade teológica, um poder centralizado na figura do soberano, com objetivo de impor a ordem dentro de um território delimitado, por meio do direito e das armas, sem limites a sua atuação externa.

\section{VITÓRIA E A LEGITIMAÇÃO DA CONQUISTA}

A base do pensamento político medieval é a de que todo poder tem origem no poder divino. Com o rompimento da universalidade cristã e a fragmentação em nações que reivindicou poderes exclusivos sobre um território, rompeu-se a dualidade Igreja e Império. Segundo Weckmann ${ }^{42}$, esta é a marca da passagem do pensamento medieval para o moderno.

Assim, a conquista na Igreja do século XVI, apesar de ser ainda uma necessidade cristã, já não se sustentaria tão somente no poder temporal do Papa. A legitimidade da concessão das terras americanas aos espanhóis mediante a doação papal por meio da Bula Inter Coetera foi intensamente discutida por juristas e teólogos, encontrando seu ponto máximo no debate travado entre Bartolomeu de Las Casas e Ginés de Sepúlveda, na Junta de Valladolid.

Francisco de Vitória na sua Releitura "Sobre los índios" não se afastou dos ideais universalistas da Igreja, pois, ao tratar dos títulos legítimos pelos quais os bárbaros poderiam cair em poder dos espanhóis, defendeu o direito de predicação do evangelho:

Quarta conclusão: Se os bárbaros, tanto os senhores mesmos, como o povo, impediram aos espanhóis anunciar livremente o Evangelho, este podem predicar mesmo contra a vontade daqueles, dando antes razão disto para evitar o escândalo, e podem procurar a conversão daquelas gentes, y se fosse necessário aceitar a guerra o declara-la por este motivo, até que deem oportunidade e segurança para predicar o Evangelho. ${ }^{43}$

\footnotetext{
${ }^{41}$ MAQUIAVEL, Nicolau. O príncipe. 2. ed. São Paulo: Martins Fontes, 1999, p. 25-26.

${ }^{42}$ WECKMANN, Luis. El pensamiento político medieval y los orígenes del derecho internacional. 2. ed. Mexico DF: Fondo de Cultura Mexicano, 1993, p. 175.

${ }^{43}$ No original: "Cuarta conclusión: Si los bárbaros, tanto los señores mismos, como el pueblo, impidieran a los espanõles anunciar libremente el Evangelio, éstos pueden predicar aun contra la voluntad de aquéllos, dando antes razón de ello para evitar el escándalo, y pueden procurar la conversión de aquellas gentes, y si fuera necesario aceptar la guerra o declararla por este motivo, hasta que den oportunidade y seguridades para predicar el Evangelio."[...] In: VITORIA, Francisco de. Sobre el poder civil. Sobre los indios. Sobre el derecho de la guerra. Madrid: Editorial Tecnos, 1998, p. 141-142.
} 
Apesar de defender o direito de guerra para a evangelização, Vitória distanciou-se de dois pilares fundamentais do pensamento medieval: refutou o poder temporal do papa e do imperador sobre toda a terra. Concluiu em sua Releitura que o imperador não era senhor de todo o orbe e, ainda que o fosse, não poderia ocupar o território dos bárbaros nem estabelecer novos senhores, porque, dentre outros argumentos, isto seria contrário ao direito natural dos povos. Também negou ao papa o poder civil sobre a terra. ${ }^{44}$

Francisco de Vitória é apontado como um marco na transição do pensamento medieval e moderno. É assim que defendeu como o primeiro título legítimo do domínio dos espanhóis sobre os índios o direito à comunicação natural entre os homens, o que implicaria a livre circulação e o comércio:

[...] é lícito aos espanhóis comerciar com eles, mas sem prejuízo para sua pátria, por exemplo, importando as mercadorias das que eles carecem e exportando dali ouro e prata e outros produtos que abundam entre eles. E os príncipes não podem impedir a seus súditos que comercializem com os espanhóis; nem tampouco os príncipes espanhóis podem proibir o comercio com eles. ${ }^{45}$

Diante deste contexto de transição paradigmática, denominada por Jaime Bruffau Prats $^{46}$ como "encruzilhada histórica", é possível observar-se um "ir e vir" no pensamento do teólogo. Neste sentido, Francisco de Vitória ${ }^{47}$ defendeu que o papa, além de ter poderes para atribuir exclusividade na predicação do Evangelho no Novo Mundo aos espanhóis, poderia também proibir o comércio a outras nações se isto se mostrasse conveniente para a propagação da fé cristã.

Apesar de a lógica da legitimação do poder espanhol nas novas terras não se fundar mais na visão medieval dos poderes temporais do papa, trazendo a marca da modernidade no direito entre os povos, em Vitória, esta defesa ainda tinha suas raízes fincadas na ética cristã.

\footnotetext{
${ }^{44}$ VITORIA, Francisco de. Sobre el poder civil. Sobre los indios. Sobre el derecho de la guerra. Madrid: Editorial Tecnos, 1998, p. 132.

${ }^{45}$ No original: “[...] es lícito a los españoles comerciar com ellos, pero sin perjuicio para su patria, por ejemplo importando las mercancías de las que ellos carecen y exportando de allí oro o plata y otros productos que abundan entre ellos. Y los príncipes no pueden impedir a los súdbitos que comercien con los españoles; ni tampoco los príncipes espanõles pueden prohibir el comerciar com ellos". In: VITORIA, Francisco de. Sobre el poder civil. Sobre los indios. Sobre el derecho de la guerra. Madrid: Editorial Tecnos, 1998, p. 132.

${ }^{46}$ PRATS, Jaime Brufau. La escuela de Salamanca ante el descubrimiento del Nuevo Mundo. Salamanca: San Esteba, 1989, p. 113.

${ }^{47}$ VITORIA, Francisco de. Sobre el poder civil. Sobre los indios. Sobre el derecho de la guerra. Madrid: Editorial Tecnos 1998, p. 140.
} 


\section{CONCLUSÃO}

A transição do mundo medieval para o mundo moderno, marcada pelo abandono da concepção da unidade cristã para os particularismos de Estado, revelou-se tanto no pensamento da Escolástica Espanhola quanto do Humanismo Renascentista. Neste cenário, as justificações das guerras de conquista também sofreram modificações.

Maquiavel, inserido no contexto do Renascimento tardio, no qual se buscava o “aconselhamento dos príncipes" com base no ideal da virtù, justificou a conquista e a submissão de outros povos na razão do Estado e no objetivo de manutenção da paz e estabilidade. 0 Humanismo Renascentista, escola à qual pertenceu, teve por premissa o homem como senhor de seu destino, sendo que a conquista é justificada com base no seu ideal civilizatório.

Francisco de Vitória, teólogo-jurista, ainda legitimava a conquista com base na visão universalista cristã e na necessidade de difusão do Evangelho. Contudo, o teólogo, precursor do Direito Internacional, argumentou também com base no direito de comunicação natural entre os povos, o que indica a modernidade de seu pensamento, reconhecendo a necessidade do comércio internacional.

Se a Escolástica Espanhola discutiu a possibilidade da guerra justa com base na predicação do Evangelho, a Renascença rompeu com a moralidade cristã e afirmou o direito de conquista com base na suposta superioridade dos iguais, em condições de civilizar os recémencontrados povos ameríndios. Nicolau Maquiavel, súdito de uma Itália cuja realidade era muito diferente da Espanha unificada e forte do "século de ouro", preocupou-se com a questão da estabilidade, segurança e paz no reino, e é considerado um marco na teoria política moderna, desprendida da moralidade cristã, contribuindo na formação do ideal do Estado Moderno. Francisco de Vitória pensou o mundo sob o ponto de vista da Espanha fortalecida pela unificação operada pelos príncipes católicos, saindo na frente das conquistas ultramarinas. É assim que este autor favoreceu o florescimento da primeira modernidade hispânica e lançou bases para a formação da doutrina moderna do direito internacional.

A análise do pensamento destes dois autores clássicos do período, Nicolau Maquiavel e Francisco de Vitória, e de suas respectivas escolas, o Humanismo Renascentista e a Escolástica Espanhola, demonstrou que o homem do século XVI, apesar das mudanças de paradigmas, seguiu 
justificando as guerras de conquistas, quer seja a partir do cristianismo, ou a partir de uma ordem natural.

\section{REFERÊNCIAS}

BARTH, Sérgio. Maquiavelismo: a prática política segundo Nicolau Maquiavel. São Paulo: Ática, 1992. (Série Princípios).

BRAUDEL, Fernand. Gramática das civilizações. São Paulo: Martins Fontes, 2004.

CHEVALLIER, Jean-Jacques. A grandes obras políticas de Maquiavel a nossos dias. 8. ed. Rio de Janeiro: Agir, 2002.

CROSSMAN, Richard Howard Stafford. Biografía del Estado Moderno. 2. ed. Madrid: Fundo de Cultura Económica de España, 1965. (Colección Popular).

DUSSEL, Enrique. Ética da libertação: na idade da globalização e da exclusão. Petrópolis: Vozes, 2000.

FERRAJOLI, Luigi. A soberania no mundo moderno: nascimento e crise do Estado Nacional. São Paulo: Martins Fontes, 2002.

MAQUIAVEL, Nicolau. O príncipe. 2. ed. São Paulo: Martins Fontes, 1999. (Clássicos).

MARTINS, Carlos Estevam (Consult.). Maquiavel: vida e obra. In: MAQUIAVEL, Nicolau. O Príncipe e escritos políticos. 4. ed. São Paulo: Nova Cultural, 1987. (Os Pensadores),

MORAES, Lauro Escorel. Maquiavel e o pensamento político. Maquiavel: um seminário da Universidade de Brasília, Cadernos da UnB. Brasília: Editora Universidade de Brasília, 1981.

PANIZZA, Diego. Introdução. In: GENTILI, Alberico. O direito de guerra. Ijuí: Unijuí, 2005.

PRATS, Jaime Brufau. La escuela de Salamanca ante el descubrimiento del Nuevo Mundo. Salamanca: San Esteba, 1989.

RANGEL, Jesús Antonio de la Torre. El derecho como manifestación del humanismo clásico español: Francisco de Vitória, Luis de Molina y Francisco Suárez. In: WOLKMER, Antônio C. Fundamentos do humanismo jurídico no Ocidente. Barueri: Manole; Florianópolis: Funjab, 2005.

RUBIO, María José; VARAS, Jesús. El análisis de la realidad en la intervención social: métodos y técnicas de investigación. 3. ed. Madrid: CCS, 2004.

RUIZ, Rafael. Francisco de Vitoria e os direitos dos índios americanos. Porto Alegre: EDIPURS, 2002. 
SADEK, Maria Tereza. Nicolau Maquiavel: o cidadão sem fortuna, o intelectual de virtú. In: WEFFORT, Francisco C. (Org.). Os clássicos da política. (Vol. 1). 2. ed. São Paulo: Ática, 1991.

SKINNER, Quentin. As fundações do pensamento político moderno. São Paulo: Companhia das Letras, 1996.

SOUZA LIMA, Antonio Carlos de. Um grande cerco de paz: poder tutelar, indianidade e formação do Estado no Brasil. Petrópolis: Vozes, 1995.

TRUYOL Y SERRA, Antonio. Historia del derecho internacional público. Madrid: Tecnos, 1998.

VITORIA, Francisco de. Sobre el poder civil. Sobre los indios. Sobre el derecho de la guerra. Madrid: Editorial Tecnos, 1998.

WECKMANN, Luis. El pensamiento político medieval y los orígenes del derecho internacional. 2. ed. Mexico DF: Fondo de Cultura Mexicano, 1993.

Recebido em: 18/09/2016 / Revisões requeridas em: 16/12/2016 / Aprovado em: 06/02/2017 